«Системні технології» 1 (126) 2020 «System technologies»

DOI 10.34185/1562-9945-1-126-2020-07

UDC 004.42:543.572.3

A.I. Ivon, V.F. Istushkin, V.V. Krokhin, S.V. Savran

\title{
WEB APPLICATION FOR MEASURING OF THE COMPONENTS CONTENT WITH PHASE TRANSITION IN HETEROGENEOUS MATERIALS
}

Abstract. The possibility of using raster images to improve the accuracy of processing differential thermal analysis (DTA) data is considered. Estimation of error in measuring of components content with a phase transition in heterogeneous materials by the DTA data presented in the form of raster images was made. Using languages HTML, CSS, JavaScript as well as Canvas technology, a web-application for processing DTA data presented as raster images was created. The application allows measuring the relative content of components with a phase transition in heterogeneous materials with an error of $\pm 3 \%$ by scan data of peaks in DTA curves. The application created in this work can use any Internet browser as a software environment.

Keywords: web application, raster image, determination of parameters by scan data, differential thermal analysis.

Problem statement and purpose of research. Research data is often obtained in visual form. Such data can be oscillograms of signals, the results of differential thermal analysis (DTA), of microscopy, and others. To increase the accuracy of measurements based on such data, they must be digitized. Digitization for visual information takes the form of the raster (digital) images [1]. If the instruments recording the visual information do not initially present it as a raster image, digitization can be performed by photographing the output data of these instruments with a digital camera.

The necessary information can be extracted from a raster image by the scanning and subsequent calculations based on the scan data. This requires the creation of programs for processing raster images. Significant opportunities for such processing are provided by means used in the Internet: HTML, CSS and object-oriented programming language JavaScript.

HTML and CSS languages allow creating a convenient user interface in the form a web page. JavaScript language provides all necessary means for

(C) Ivon A.I., Istushkin V.F., Krokhin V.V., Savran S.V., 2020 
processing of raster images. Any Internet browser can be the software environment for web applications created by these languages.

In a study of the processes in materials associated with phase transitions (PT), the differential thermal analysis method [2] is widely used. The results of this method are usually obtained in visual form. The presence of endothermic and exothermic peaks in the DTA data not only identifies the phase transition in the material, but also makes it possible to obtain from these peaks information on temperature and heat of phase transition. DTA data of heterogeneous materials containing a component with a phase transition make it possible to measure the content of this component. Such measurement can be performed by comparing the peak areas for DTA curves of the calibration sample containing $100 \%$ of the material with phase transition and heterogeneous material [3]. The area of objects in raster image can be determined with high accuracy on the base of scan data [4]. This makes it possible to use DTA data, presented in the form of raster images, for measuring with high accuracy the content of components with phase transition in heterogeneous materials.

In view of the foregoing, the purpose of this work is to create by web software a program that allows using differential thermal analysis data presented in the form of raster images to measure the relative content of components with phase transition in heterogeneous materials.

Main part. As known [3], the relative content of C component with PT in heterogeneous material can be determined from DTA data as

$$
C=\frac{S_{x} m_{e}}{S_{e} m_{x}} \cdot 100 \%=k_{e} \frac{S_{x}}{m_{x}} \cdot 100 \%,
$$

where $m_{e}, m_{x}$ are masses of calibration sample and tested material; $S_{e}, S_{x}$ are the peak areas associated with PT in the DTA curves of calibration sample and tested material; $k_{e}=m_{e} / S_{e}$ is the calibration coefficient.

If DTA data is presented as a raster image, then after scanning along the contour of DTA peak associated with phase transition, the array of points coordinates in pixels $x_{i}, y_{i}(1 \leq i \leq \mathrm{N})$ can be obtained. On the basis of this array, one can calculate the peak area by using the Gauss formula [5] as 
«Системні технологіï» 1 (126) 2020 «System technologies»

$$
S=\frac{1}{2}\left|x_{N} y_{1}-x_{1} y_{N}+\sum_{i=1}^{N-1}\left(x_{i} y_{i+1}-x_{i+1} y_{i}\right)\right| .
$$

In the case where the DTA data for calibration sample and tested material are recorded under the same conditions (the same heating rate and sensitivity of DTA), it is possible to determine in accordance with (1) the relative content of component with phase transition in heterogeneous material by performing the scanning of DTA peak for the tested sample and calculation the value of $S_{x}$ in accordance with the formula (2). Taking into account (1) and neglecting the small error in determining the mass during analytical weighing, we can obtain the assessed value of the absolute error at determining $C$ :

$$
\Delta C= \pm k_{e} \frac{\Delta S_{x}}{m_{x}} \cdot 100 \% .
$$

If we do not take into account the blurriness of DTA lines, then the absolute error at scanning of the points coordinates in raster image is equal to the quantization step of 1 pixel. Therefore, when the length of contour along which the DTA peak of tested material was scanned is equal to $\mathrm{P}$, we can estimate the absolute error in determining of the area $\Delta S_{x}$ on the basis of scan data $x_{i}, y_{i}(1 \leq i \leq \mathrm{N})$ in the following way:

$$
\Delta S_{x}=P \cdot 1 \text { пик. }=\sqrt{\left(x_{1}-x_{N}\right)^{2}+\left(y_{1}-y_{N}\right)^{2}}+\sum_{i=1}^{N-1} \sqrt{\left(x_{i}-x_{i+1}\right)^{2}+\left(y_{i}-y_{i+1}\right)^{2}}
$$

Formulas (1) - (4) were used in the scripts of program to perform the necessary calculations.

The algorithm used in the program for processing raster images of DTA data includes the following steps: 1). Download of raster image to a browser window; 2). Scanning of the DTA peak for calibration sample; 3). Calculation of the calibration coefficient $\left.k_{e} ; 4\right)$. Scanning of the DTA peak for tested sample; 5). Calculation on the basis of scan data the relative content of the component with a phase transition in heterogeneous material $\mathrm{C}$ and the absolute measurement error $\Delta C$; 6). Output results of measurement.

Fig. 1 shows a program window at the initial stage of processing. The program is open in Opera browser. To enable the use of Canvas tools on web 
page a canvas with sizes of $2300 \times 2600$ pixels is created. In the upper left corner of program window the block displaying the current coordinates of the mouse cursor is situated. This block contains two hidden form fields that display the current coordinates of the mouse cursor $x$ and $y$. The block serves a script that is started by mousemove event. The pageX and pageY properties of the event object in JavaScript are used to read the cursor coordinates. In the upper right corner of the browser window a toolkit block is situated. This block contains a set of buttons designed to run scripts serving various stages of processing of the raster images.

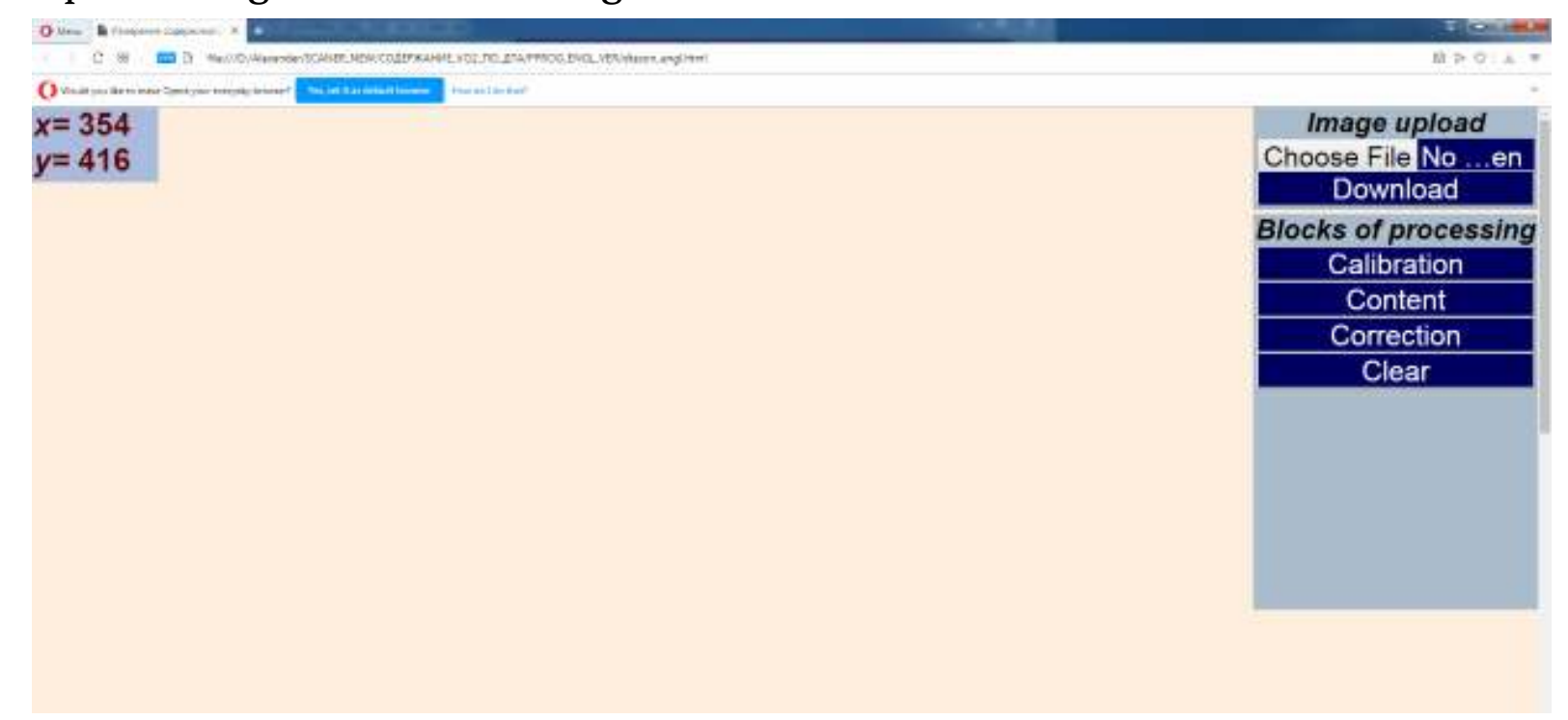

Figure 1 - Program window at the initial stage of processing

For loading of raster images, the file type field is used. When pressing "Choose File", a window opens that allows selecting the file of the desired raster image and a script starts for loading image into the browser window. This script uses a FileReader object with the appropriate methods and properties. The button "Download" is used for transfer a raster image to the canvas and its concealment outside the canvas. This button starts a script that, through the drawImage() method of the canvas object, transfers the image to the canvas and provides its concealment outside the canvas using the hidden property of the style object.

Fig. 2 shows the program window after loading a raster image of DTA data for powders of crystalline vanadium dioxide $\mathrm{VO}_{2}$ and for ceramics based on $\mathrm{VO}_{2}$ (wt.\%) $30 \mathrm{VO}_{2}-15 \mathrm{VPG}-5 \mathrm{Cu}-50 \mathrm{SnO}_{2}$ (VPG -vanadium-phosphate glass). 
«Системні технологіï» 1 (126) 2020 «System technologies»

In different stages of processing for scanning of the points coordinates on raster image the program starts a script that uses properties page $X$ and pageY of event object. The program saves coordinates of the points into the arrays $x_{i}, y_{i}(1 \leq i \leq \mathrm{N})$. To visualize the scan points, the program uses methods and properties of Canvas technology for drawing circles and lines. The scanned dots are displayed as a white circle with a radius of 4 pixels. The center of the circle is located at the scan point with coordinates $\left(x_{i}, y_{i}\right)$. Scan points connect straight lines with a width of 3 pixels. Visualization allows evaluating the correctness of the scan. The "Correction" button is used for correction of the scan results (Fig. 2). When pressing of this button, a script is initiated that removes the coordinates of the last scanned point from $x_{i}, y_{i}$ arrays. This script erases the image of this point and the line connecting it to the previous point. Multiple pressing of "Correction" provides a cleaning of all scan data and deletes the visualization of this data in the program window.



Figure 2 - Program window after loading of the raster image: 1 - DTA curve of crystalline $\mathrm{VO}_{2}$ (the calibration sample); 2 - DTA curve of ceramics (wt. \%) $30 \mathrm{VO}_{2}-15 \mathrm{VPG}-5 \mathrm{Cu}-50 \mathrm{SnO}_{2}$. DTA recording mode: heating rate $1.25 \mathrm{~K} / \mathrm{min}$; sensitivity $1 / 3$. The mass of $\mathrm{VO}_{2}$ and ceramics samples is $508 \mathrm{mg}$ The steps of processing, relating to the determination of the calibration coefficient $k_{e}$ (steps 2, 3) begin at pressing of the "Calibration" button. Fig. 3 shows the program window after performance of these steps. 


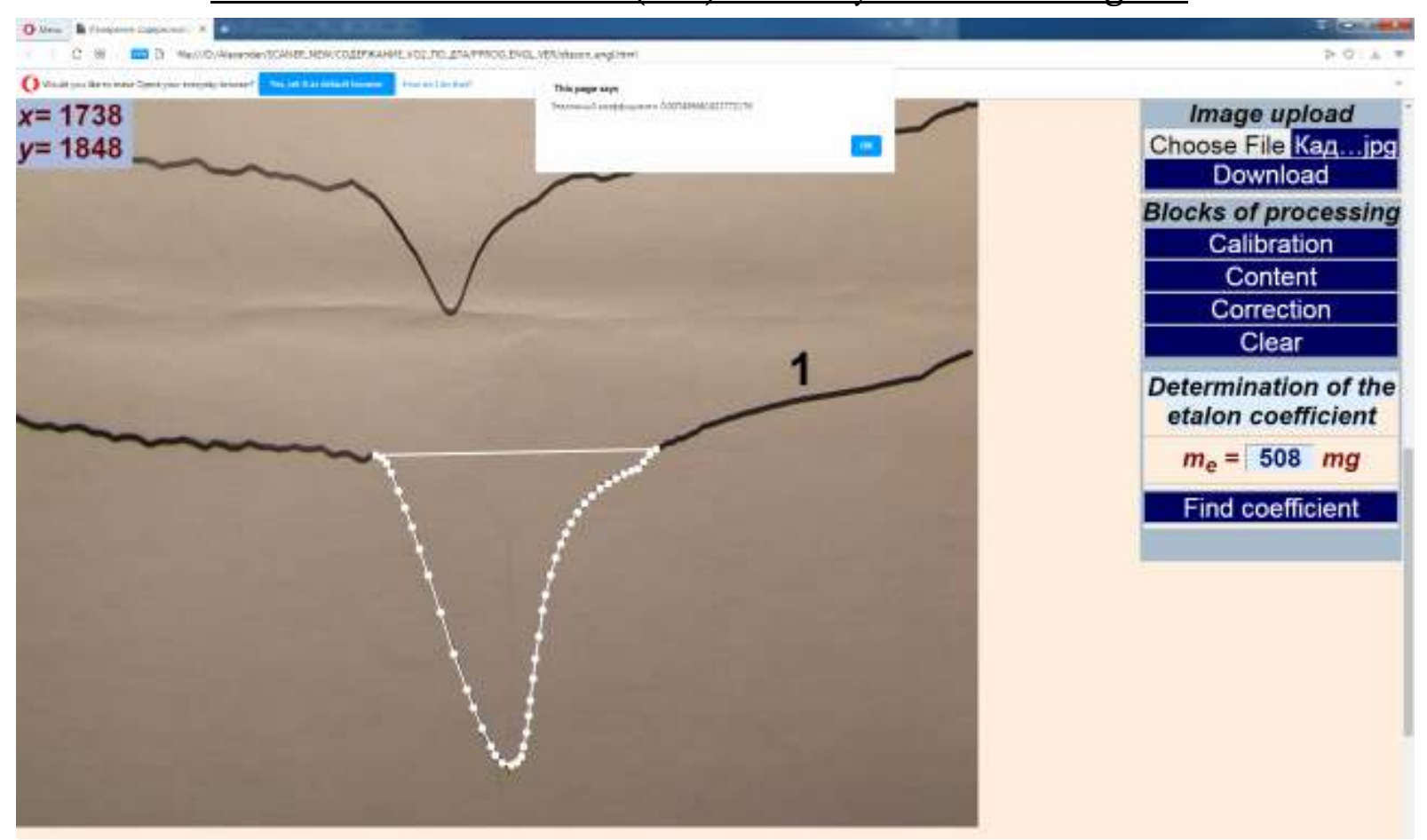

Figure 3 - Program window after completing the determination of calibration coefficient

As it can be seen in Fig. 3, at performing the steps of $k_{e}$ determination, the user must introduce the mass of calibration sample $m_{e}$ in the form field and perform a scanning along the DTA contour of the peak for this sample. The calculation of $k_{e}$ occurs after pressing the "Find coefficient" button. The script serving these processing steps contains means for checking the filling of the " $m_{e}=$ " form and performing a scan. If the form is empty or the scan is unperformed, the alert() method opens a dialog window with the corresponding message. The value of the calibration coefficient $k_{e}$ in units of $\mathrm{mg} / \mathrm{pixel}^{2}$ can be seen in window opened by alert() method after pressing the "Find coefficient" button (Fig. 3).

When pressing the "Content" button, the transition to processing steps associated with the measurement of relative content of component with phase transition in the heterogeneous material takes place. The user must introduce the mass of the testing sample in the " $m_{x}=$ " form field and scan the DTA peak of this sample. When pressing the "Calculate content" button, the program performs calculations according to formulas (1) - (4) and displays the measurement results in the hidden form fields (Fig. 4). 


\section{«Системні технологіï» 1 (126) 2020 «System technologies»}

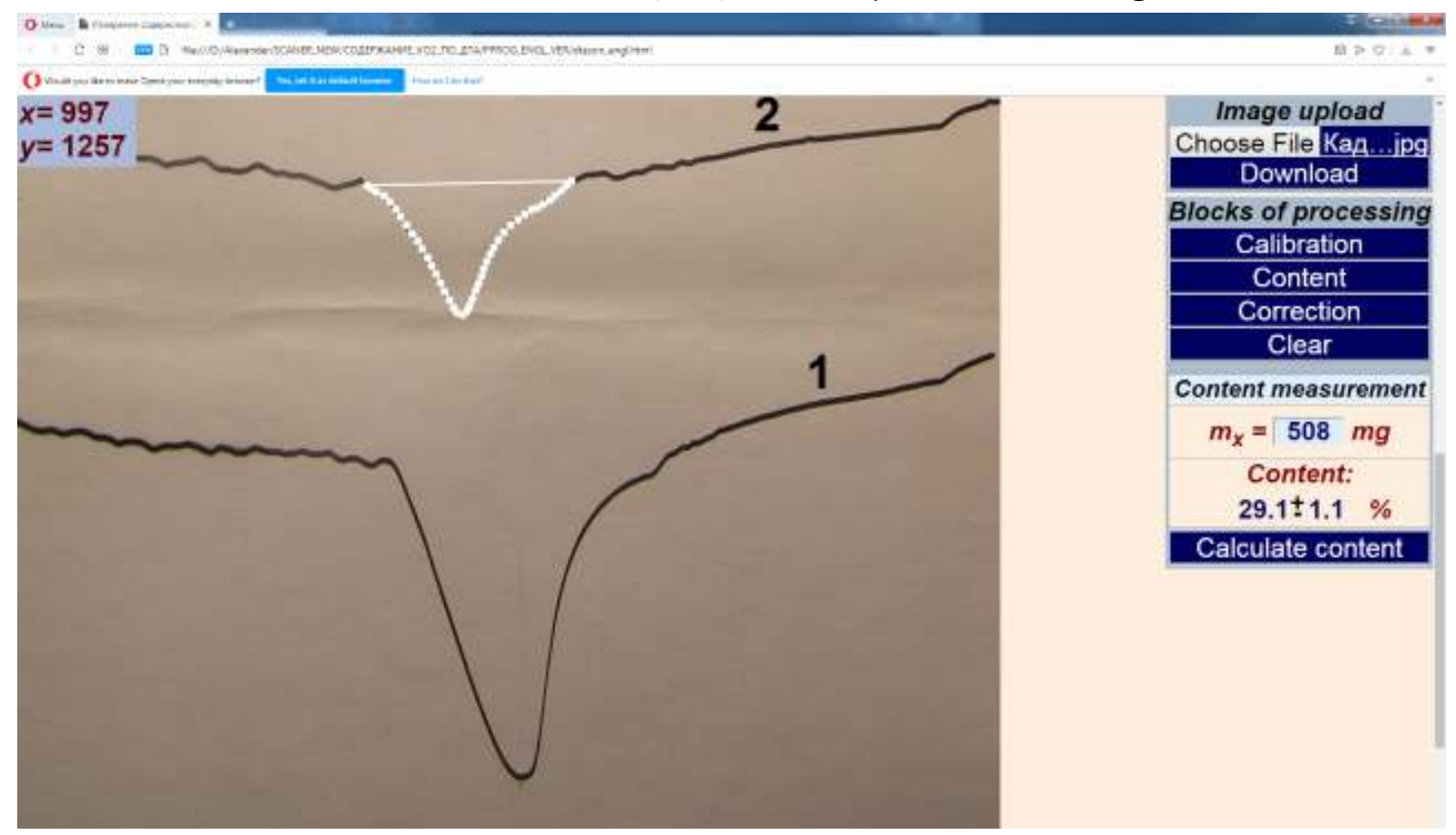

Figure 4 - The program window at the final stage of execution

The toolkit block of the program has the "Clear" button (Fig. 4). Pressing this button clears the arrays $x_{i}, y_{i}$ of scanned coordinates and deletes the visual scan results. In this case the program stores the value of the calibration coefficient $k_{e}$. This allows re-measuring the content of the component with the phase transition in the same sample or for other samples whose DTA data are presented in the image without reloading raster image and without determining the value of $k_{e}$.

The raster images of DTA data allows measuring the relative content of component with phase transition in heterogeneous material with a relative error of about $\pm 3 \%$, when processing is executed using the program described above.

Conclusions. The program for processing raster images with differential thermal analysis data was created by languages that are used for the information presenting on the Internet (HTML, CSS, JavaScript). The program is implemented as a web application that allows using the scan data of DTA peaks to measure the relative content of components with a phase transition in heterogeneous materials. The measurement accuracy is $\sim \pm 3 \%$. The application can use any Internet browser as a software environment. 


\section{«Системні технології» 1 (126) 2020 «System technologies»}

\section{ЛИТЕРАТУРА / ЛІТЕРАТУРА}

1. Сиденко Л. А. Компьютерная графика и геометрическое моделирование: учеб. пособие. - СПб: Питер, 2009. - 224 с.

2. Wendlandt W.W. Thermal Analisis. - New York: Wiley-Interscience, 1986. $832 \mathrm{p}$.

3. Ивон А.И. Определение содержания кристаллического диоксида ванадия в материалах на его основе / А.И. Ивон, Т.А. Бубель // Заводская лаборатория. Диагностика материалов. - 2005.- Т.71, №8. - с. 31-35.

4. Ivon A.I. Web application for measurement of the sizes and area of objects by satellite photography / A.I. Ivon, V.F. Istushkin, Yu.M. Rybka // Системні технології. -2019. - вип. 1' (120). - с. 89-95.

5. Gauss area formula. Wikipedia - free encyclopedia: website. URL: https://en.wikipedia.org/wiki/Shoelace_formula.

\section{REFERENCES}

1. Sidenko L.A. Kompyuternaya grafika i geometricheskoe modelirovanie: ucheb. posobie - SPb: Piter, 2009. - $224 \mathrm{~s}$.

2. Wendlandt W.W. Thermal Analisis. - New York: Wiley-Interscience, 1986. $832 \mathrm{p}$.

3. Ivon A.I. Opredelenie soderrzhaniya kristallicheskogo dioksida vanadiya v materialah na ego osnove / A.I. Ivon, T.A. Bubel // Zavodskaya laboratoriya. Diagnostika materialov. - 2005.- T.71, №8. - p. 31-35.

4. Ivon A.I. Web application for measurement of the sizes and area of objects by satellite photography / A.I. Ivon, V.F. Istushkin, Yu.M. Rybka // System technologies. -2019. - issue 1' (120). - p. 89-95.

5. Gauss area formula. Wikipedia - free encyclopedia: website. URL: https://en.wikipedia.org/wiki/Shoelace_formula.

\section{Веб додаток для вимірювання вмісту компонентів}

Received 16.01.2020. Accepted 20.01.2020.

\section{з фазовим переходому гетерогенних матеріалах}

В роботі розглянуто можливість використання растрових (цифрових) зображень для підвищення точності обробки даних диференціального термічного аналізу (ДТА). Дані ДТА, що звичайно отримують у не цифрованій формі, можуть бути цифровані шляхом фотографування цифровою фотокамерою. Виконано оцінку похибки вимірювання вмісту компоненту з фазовим переходом у гетерогенному матеріалі за даними ДТА поданими у вигляді растрового зображення. Засобами мов HTML, CSS, JavaScript i технології Canvas створено прикладний вев-додаток для обробки даних ДТА, поданих як растрові зображення. Додаток на підставі даних сканування піків ДТА калібрувального і вимірюваного зразка дозволяє визначити вміст компоненту з фазовим переходом у гетерогенному 74 
«Системні технології» 1 (126) 2020 «System technologies»

матеріалі з відносною похибкою $\pm 3 \%$. Додаток, створений в роботі, може використовувати, як програмне середовище будь який браузер мережі Iнтернет.

\section{Веб приложение для измерения содержания компонентов}

с фазовым переходом в гетерогенных материалах

В работе рассмотрена возможность использования растровых (цифровых) изображений для повышения точности обработки данных дифференциального термического анализа. Данные ДТА, которые обычно получают в нецифровой форме, могут быть оцифрованы путем фотографирования цифровой фотокамерой. Выполнена оценка погрешности измерения содержания компонента с фазовым переходом в гетерогенном материале по данным ДТА, представленным как растровое изображение. Средствами языков HTML, CSS, JavaScript и технологии Canvas создано прикладное веб-приложение для обработки данных ДТА, представленных как растровые изображения. Приложение на основании данных сканирования пиков ДТА калибровочного и измеряемого образца позволяет определить содержание компонента с фазовым переходом в гетерогенном материале $c$ относительной погрешностью $\pm 3 \%$. Приложение, созданное в работе, может использовать в качестве программной среды любой браузер сети Интернет

Ивон Александр Иванович - профессор, д.ф.-м.н, профессор кафедры электронных вычислительных машин Днепровского национального университета имени Олеся Гончара.

Истушкин Валерий Федорович - доцент, к.т.н., доцент кафедры электронных вычислительных машин Днепровского национального университета имени Олеся Гончара.

Крохин Владимир Викторович - доцент, к.ф.-м.н., доцент кафедры электронных вычислительных машин Днепровского национального университету имени Олеся Гончара.

Савран Сергей Викторович - аспирант кафедры электронных вычислительных машин факультета физики, электроники и компьютерных систем Днепровского национального университета имени Олеся Гончара.

Івон Олександр Іванович - професор, д.ф.-м.н, професор кафедри електронних обчислювальних машин Дніпровського національного університету імені Олеся Гончара.

Істушкін Валерій Федорович - доцент, к.т.н., доцент кафедри електронних обчислювальних машин Дніпровського національного університету імені Олеся Гончара.

Крохін Володимир Вікторович - доцент, к.ф.-м.н., доцент кафедри електронних обчислювальних машин Дніпровського національного університету імені Олеся Гончара. 
Савран Сергій Вікторович - аспірант кафедри електронних обчислювальних машин факультету фізики, електроніки та комп'ютерних систем Дніпровського національного університету імені Олеся Гончара.

Ivon Alexander - doctor of sciences (physics and mathematics), professor of the department of electronic computers of the faculty of physics electronics and computer systems of the Oles Honchar Dnipro National University.

Istushkin Valery - candidate of technical sciences, associate professor of the department of electronic computers of the faculty of physics electronics and computer systems of the Oles Honchar Dnipro National University.

Krokhin Vladimir - associate professor of computer systems engineering Department of the Oles Honchar Dnipro National University.

Savran Sergey - post-graduate student of the department of electronic computers of the faculty of physics electronics and computer systems of the Oles Honchar Dnipro National University. 